\title{
A STUDY ON EFFECT OF BACTERIA ON CEMENT COMPOSITES
}

\author{
Vijeth N Kashyap ${ }^{1}$, Radhakrishna ${ }^{2}$ \\ ${ }^{1} P G$ Student, ${ }^{2}$ Associate Professor, Dept of Civil Engineering, $R$ V College of Engineering, $R$ V Vidyanikethan Post, \\ Mysore Road, Bangalore. \\ vijethnkashyap@gmail.com,chakavelu_rk@yahoo.com
}

\begin{abstract}
Crack is commonly observed failure in the case of concrete. Crack may develop due to addition of excess of water to during mixing of concrete, or may be due to shrinkage and creep. In the present study, crack healing and improvement of physical properties of cement paste, mortar and concrete are studied. It is done by the addition of bacterial strains namely Bacillus Sphaericus and Sporosarcina Pastuerii. It is found that these bacteria when added at $10^{6}$ concentration of cells/ml of water to cement composites increased by about $39.8 \%$ and $33.07 \%$ in paste. There is an increment of $50 \%$ and $28.2 \%$ in mortar for two bacterial strains. The strength increment is found to be $18.3 \%$ and $12.2 \%$ for Bacillus Sphaericus and Sporosarcina Pastuerii respectively for concrete. Ultrasonic pulse velocity of the bacterial concrete was in line with conventional concrete. SEM and XRD images revealed presence of CaCO $\mathrm{B}_{3}$ produced microbially. There is overall improvement in the bacterial composites compared to conventional composites.
\end{abstract}

Keywords: Bacillus Sphaericus, Sporosarcina Pastuerii Bacteria, Crack, Concentration, and Calcite. $* * *$

\section{INTRODUCTION}

In concrete, cracking is a common phenomenon due to the relatively low tensile strength. Durability of concrete is also impaired by these cracks, since they provide an easy path for the transport of liquids and gasses that potentially contain harmful substances. For crack repair, a variety of techniques is available but traditional repair systems have a number of disadvantageous aspects such as different thermal expansion coefficient compared to concrete and environmental and health hazards. Therefore, bacterially induced calcium carbonate precipitation has been proposed as an alternative and environmental friendly crack repair technique. Microbial calcite precipitation is mainly due to urealytic activity and carbonate biomineralization of bacteria. The bacteria used in this research produce urease which catalyzes the hydrolysis of urea $\left(\mathrm{CO}\left(\mathrm{NH}_{2}\right)_{2}\right)$ into ammonium $\left(\mathrm{NH}_{4}{ }^{+}\right)$and carbonate $\left(\mathrm{CO}_{3}\right.$ ${ }^{2-}$ ) [1], First, $1 \mathrm{~mol}$ of urea is hydrolyzed intracellular to $1 \mathrm{~mol}$ of carbonate and $1 \mathrm{~mol}$ of ammonia (Eq. (1)). Carbonate spontaneously hydrolyses to form additionally $1 \mathrm{~mol}$ of ammonia and carbonic acid (Eq. (2)). These products subsequently form $1 \mathrm{~mol}$ of bicarbonate and $2 \mathrm{~mol}$ of ammonium and hydroxide ions (Eqs. (3) and (4)). The last 2 reactions give rise to a $\mathrm{pH}$ increase, which in turn shifts the bicarbonate equilibrium, resulting in the formation of carbonate ions (Eq. (5)).[2]

$$
\begin{aligned}
& \mathrm{CO}\left(\mathrm{NH}_{2}\right)_{2}+\mathrm{H}_{2} \mathrm{O} \Rightarrow \mathrm{NH} 2 \mathrm{COOH}+\mathrm{NH} 3 \\
& \mathrm{NH}_{2} \mathrm{COOH}+\mathrm{H}_{2} \mathrm{O} \Rightarrow \mathrm{NH} 3+\mathrm{H} 2 \mathrm{CO} 3 \\
& \mathrm{H}_{2} \mathrm{CO}_{3} \Leftrightarrow \mathrm{HCO}_{3}^{-}+\mathrm{H}^{+}
\end{aligned}
$$

$$
\begin{aligned}
& 2 \mathrm{NH}_{3}+2 \mathrm{H}_{2} \mathrm{O} \Leftrightarrow 2 \mathrm{NH}_{4}{ }^{+}+2 \mathrm{OH}^{-} \\
& \mathrm{HCO}_{3}{ }^{-}+\mathrm{H}^{+}+2 \mathrm{NH}_{4}{ }^{+}+2 \mathrm{OH}^{-} \Leftrightarrow \mathrm{CO}_{2} 2^{-}+2 \mathrm{NH}_{4}^{+}+2 \mathrm{H}_{2} \mathrm{O}
\end{aligned}
$$

Since the cell wall of the bacteria is negatively charged, the bacteria draw cat ions from the environment, including $\mathrm{Ca}^{2+}$, to deposit on their cell surface. The $\mathrm{Ca}^{2+}$ ions subsequently react with the $\mathrm{CO}_{3}{ }^{2-}$ ions, leading to the precipitation of $\mathrm{CaCO}_{3}$ at the cell surface that serves as a nucleation site (Eqs. (6) and (7))

$$
\begin{aligned}
& \mathrm{Ca}^{2+}+\text { Cell } \rightarrow \text { Cell }-\mathrm{Ca}^{2+} \\
& \text { Cell }-\mathrm{Ca}^{2+}+\mathrm{CO}_{3}{ }^{2-} \rightarrow \text { Cell }-\mathrm{CaCO}_{3} \downarrow
\end{aligned}
$$

Several bacteria have the ability to precipitate calcium carbonate. These bacteria can be found in soil, sand, natural minerals. This strain showed a high urease activity, a continuous formation of dense calcium carbonate crystals and a very negative zeta-potential [3]. Self-healing concrete is a product that will biologically produce limestone to heal cracks that appear on the surface of concrete structures. Specially selected types of the bacteria genus Bacillus, along with a calcium-based nutrient known as calcium lactate, and nitrogen and phosphorus, are added to the ingredients of the concrete when it is being mixed. These self-healing agents can lie dormant within the concrete for up to 200 years [4]. 


\subsection{Finding Right Bacteria:}

The starting point of the research is to find bacteria capable of surviving in an extreme alkaline environment. Cement and water have a $\mathrm{pH}$ value of up to 13 when mixed together, usually a hostile environment for life most organisms die in an environment with a $\mathrm{pH}$ value of 10 or above [13]. The search concentrated on microbes that thrive in alkaline environments which can be found in natural environments, Samples of endolithic bacteria (bacteria that can live inside stones) will be collected along with bacteria found in sediments in the lakes. Strains of the bacteria genus Bacillus will be found to thrive in this high-alkaline environment. Different types of bacteria which can survive in such a high Ph environment is mentioned in Table 1. It is found that the only group of bacteria that will be able to survive is the ones that produced spores comparable to plant seeds. Such spores have extremely thick cell walls that enable them to remain intact for up to 200 years while waiting for a better environment to germinate. They would become activated when the concrete starts to crack, food is available, and water seeps into the structure [19]. This process lowers the $\mathrm{pH}$ of the highly alkaline concrete to values in the range $\mathrm{pH}$ 10 to 11.5 ) where the bacterial spores become activated.

Table 1: Various microbes used in concrete [19]

\begin{tabular}{|l|l|}
\hline Applications & Types of bacteria \\
\hline \multirow{4}{*}{ As crack healer } & B. pasteurii \\
\cline { 2 - 2 } & Deleya halophila \\
\cline { 2 - 2 } & Halomonas eurihalina \\
\cline { 2 - 2 } & Myxococcus xanthus \\
\cline { 2 - 2 } & B. megaterium \\
\hline For surface treatment & B. sphaericus \\
\hline As water purifier & Bacillus subitilis \\
\cline { 2 - 2 } & B sphaericus \\
\cline { 2 - 2 } & Thiobacillus \\
\hline
\end{tabular}

\section{MATERIALS AND METHODS}

\subsection{Bacteria}

\section{Procurement of Bacteria and culturing:}

Two different bacteria namely

1) Bacillus sphaericus and

2) Sporosarcina pastuerii

These bacteria are obtained from the Microbial Type Culture Collection and Gene Bank (MTCC), Chandigarh in a freezed dried condition. Bacteria is first cultured in solid media (agar) are then transferred to nutrient broth (liquid media) which is sterile and kept in shaking incubator (to ensure uniform growth) for about 48 hrs.

\section{Bacterial Count:}

Concentration of cells is measured by Haemocytometer and optical density is found by spectrophotometer analysis before adding bacteria to cement composites.

\section{Gram Staining:}

Gram staining method was used to determine the morphology of the bacterial strains.

\section{Bacterial Activity:}

Bacterial cultures are tested for urealytic activity and also calcium carbonate precipitation.

\subsection{Properties of Materials}

i) Properties of cement as per Indian Specifications IS: 122691987.

ii) Properties of fine and coarse aggregates as per Indian Standard Specifications IS: 383.

iii) Property of water as per IS: 3025 - 1964 part 22, part 23 and IS: $456-2000$.

iv) Concrete mix proportion designed as per IS 10262-2009 to have 28- day compressive strength of minimum $25 \mathrm{MPa}$.

\subsection{Preparation of Microbial Cement Paste and}

\section{Mortar Cubes:}

$5 \mathrm{~cm}^{3}$ moulds were used. Cement paste and mortar (cement: sand, 1:3) cubes were casted by mixing grown bacterial cultures of concentration $10^{5}, 10^{6}, 10^{7}$, and $10^{8}$ cells $/ \mathrm{ml}$ of water, at a W/C ratio of 0.4 . Conventional cement paste specimens with regular water are also casted parallel. The cubes were cured under tap water at room temperature and tested at 1,7 , and 28 days.

\subsection{Preparation of Concrete Samples with Bacteria:}

Bacterial concrete casted by using ordinary Portland cement mixed with bacterial concentration $10^{6}$ cells $/ \mathrm{ml}$ of water. Conventional concrete samples were also casted in parallel. The specimens were cured under tap water at room temperature and tested at 7 , and 28 days.

\section{EXPERIMENTAL PROGRAMME:}

\section{Compressive Strength and Tensile Strength:}

Compressive strength of cement paste, mortar and concrete with bacteria is performed using automatic compression testing machine. Split tensile strength concrete with bacteria is performed.

Ultrasonic Pulse Velocity:

The time taken for the pulse to pass through the concrete is measured by electronic measuring circuits.

Scanning Electron Microscopy (SEM): The deposition of calcite inside the micro cracks of concrete by bacteria is analyzed under SEM. 


\section{X-Ray Diffraction:}

Reveals information about the crystal structure, chemical composition, and physical properties of bacterial cement composites

\section{RESULTS AND DISCUSSION}

The various results obtained from tests on bacteria to check its activity are as shown in Table 2 .

Table 2 Various test on bacteria.

\begin{tabular}{|c|c|c|}
\hline $\begin{array}{c}\text { Test } \\
\begin{array}{c}\text { Haemocytometer } \\
\text { test }\end{array}\end{array}$ & $\begin{array}{c}\text { To determine } \\
\text { concentration }\end{array}$ & $\begin{array}{c}10^{7} \text { cells/ml of } \\
\text { bacterial } \\
\text { solution }\end{array}$ \\
\hline Gram staining & Morphology & Gram positive \\
\hline Urease test & $\begin{array}{c}\text { Calcite } \\
\text { precipitation }\end{array}$ & $\begin{array}{c}\text { Color change }- \\
\text { yellow to pink }\end{array}$ \\
\hline $\mathrm{CaCO}_{3}$ test & $\begin{array}{c}\text { Quantity of } \\
\text { calcite } \\
\text { precipitation }\end{array}$ & $3 \mathrm{mg} / \mathrm{l}$ \\
\hline $\begin{array}{c}\text { Spectrophotometer } \\
\text { test }\end{array}$ & $\begin{array}{c}\text { Cell } \\
\text { concentration }\end{array}$ & $\begin{array}{c}10^{8} \text { cells/ml of } \\
\text { bacterial } \\
\text { solution }\end{array}$ \\
\hline
\end{tabular}

\subsection{Compressive Strength:}

From Fig 1 and Fig 2 confirms that the cement paste and mortar has higher strength when the concentration of cell is $10^{6}$ cells $/ \mathrm{ml}$ of water. The strength gain was about $39.8 \%$ and $33.07 \%$ in case of paste and $50 \%$ and $28.2 \%$ in mortar for Bacillus Sphaericus and Sporosarcina Pastuerii respectively compared that of conventional mix. Fig 3, shows that the compressive strength is more for bacterial concrete for concentration of $10^{6} \% \mathrm{ml}$ of water. The strength increment is found to be $18.3 \%$ and $12.2 \%$ respectively for Bacillus Sphaericus and Sporosarcina Pastuerii.

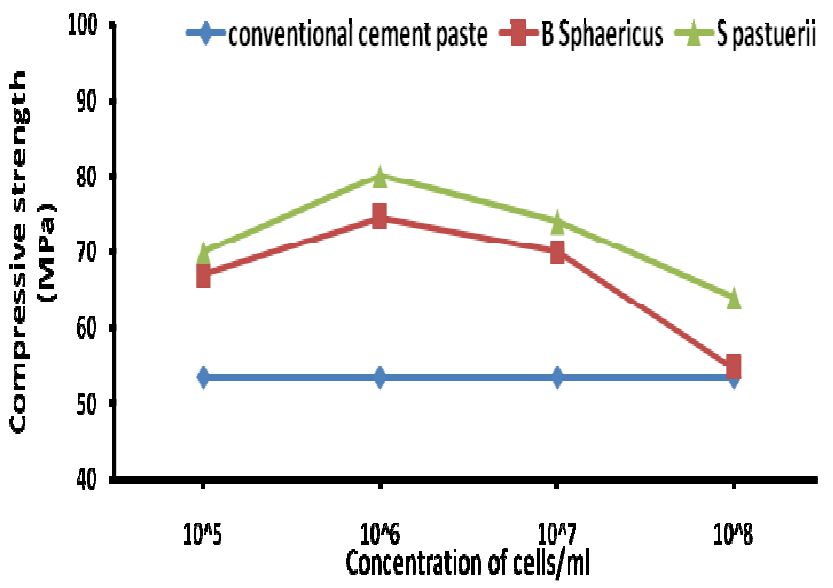

Fig 1 Compressive strength of cement paste

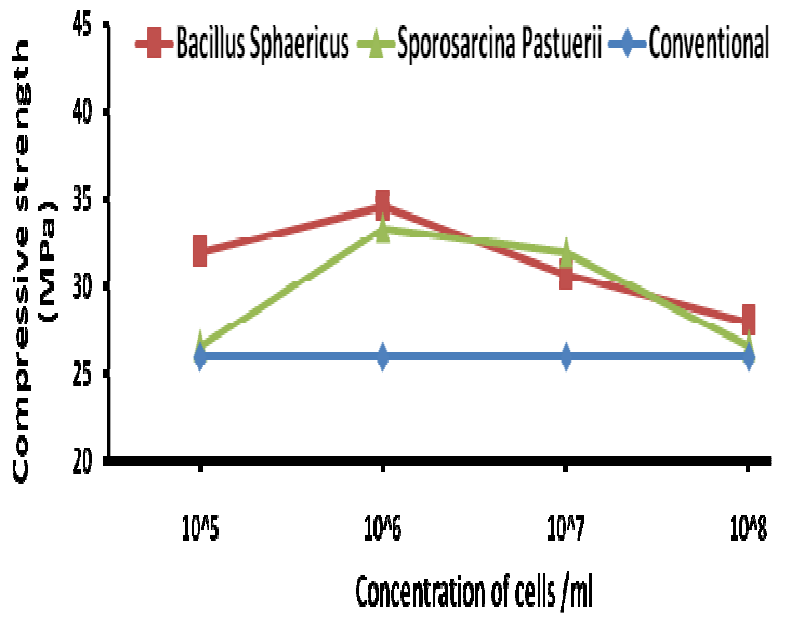

Fig 2.Compressive strength of cement mortar

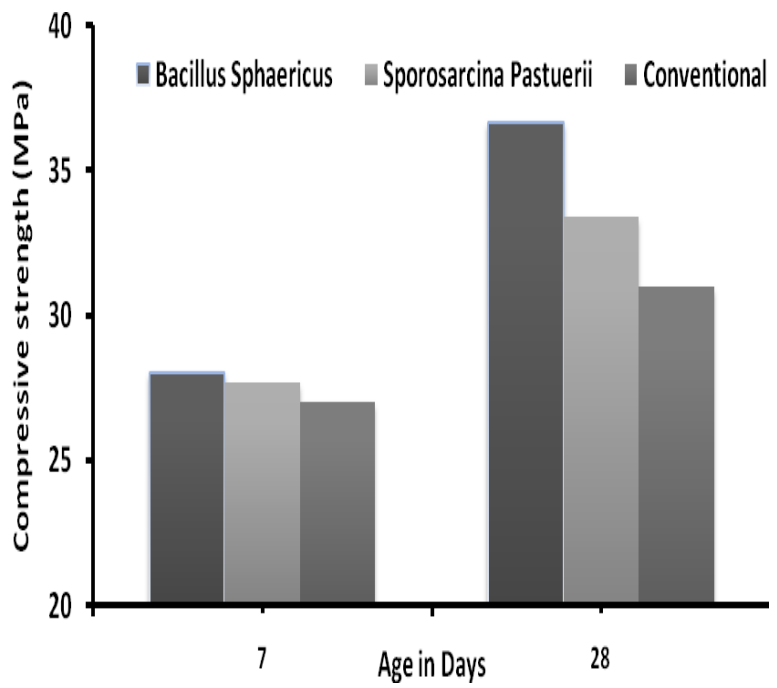

Fig 3 Compressive strength of cement concrete

\subsection{Split Tensile Strength:}

Table 2 indicates the split tensile strength of conventional and bacteria concrete. It is observed that the split tensile strength of bacterial concrete is marginally higher compared to conventional mix.

Table 2 Split tensile strength of concrete (MPa)

\begin{tabular}{|c|c|c|c|}
\hline $\begin{array}{c}\text { Age, } \\
\text { (Days) }\end{array}$ & $\begin{array}{c}\text { Convention } \\
\text { al }\end{array}$ & $\begin{array}{c}\text { B } \\
\text { Sphaericus }\end{array}$ & S Pastuerii \\
\hline 7 & 3.40 & 3.40 & 3.45 \\
\hline 28 & 3.75 & 4.60 & 4.00 \\
\hline
\end{tabular}




\subsection{Ultrasonic Pulse Velocity:}

Fig 4 shows that the ultrasonic pulse velocity of three different specimens of concrete. It can be observed that the pulse velocity of the concrete containing bacteria Bacillus Sphaericus is less compared to other two.

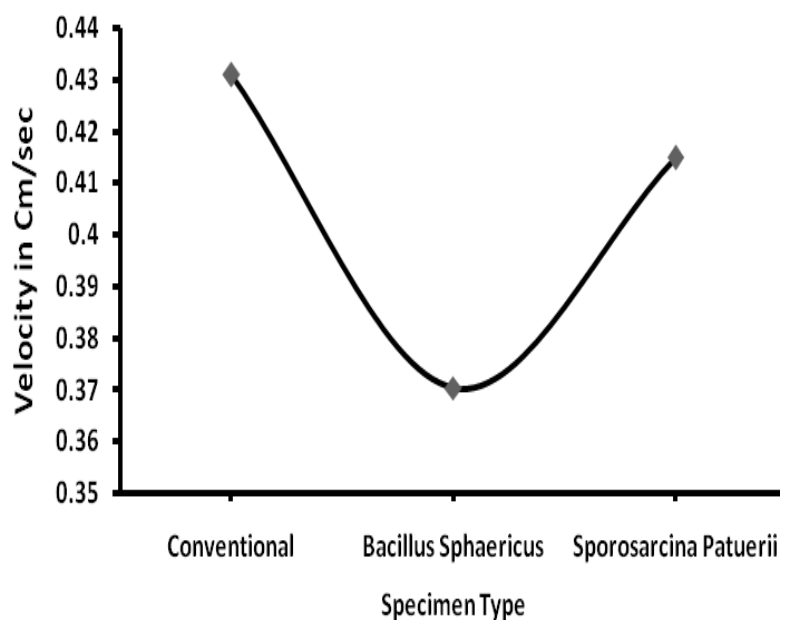

Fig 4 Ultrasonic Pulse Velocity of Concrete Specimen

\subsection{Scanning electron microscopy (SEM):}

Fig 5 shows the SEM image of bacterial cement paste. The spherical particles in the image show the presence of calcite. This microbially produced calcite is responsible in filling up the pores in cement composites and hence increasing the strength and durability.

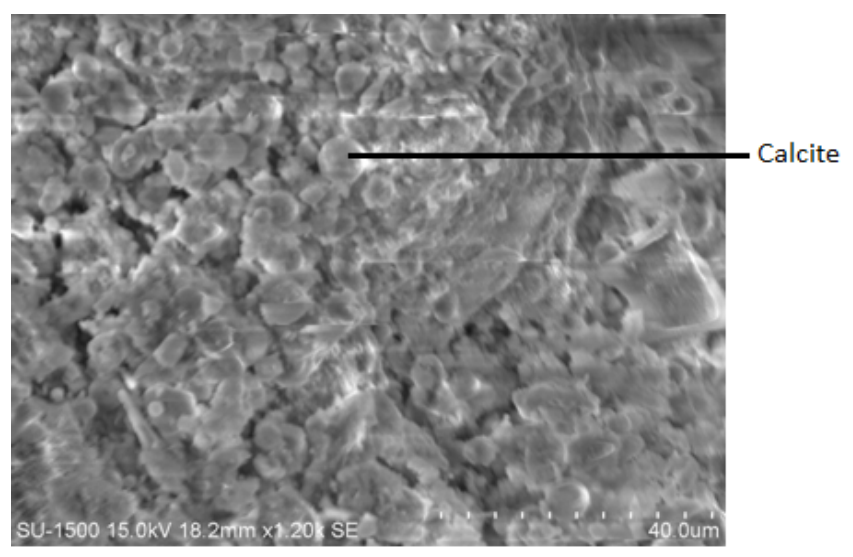

Fig 5 SEM image of bacterial cement paste

\subsection{X-Ray Diffraction (XRD):}

Fig 6 shows the XRD image of cement paste with peak at $26^{\circ}$. It indicates the presence of calcite. Higher the peak suggests the more amount of presence of calcite. Hence it can be said that this microbially precipitated calcite improves the performance of cement composites.

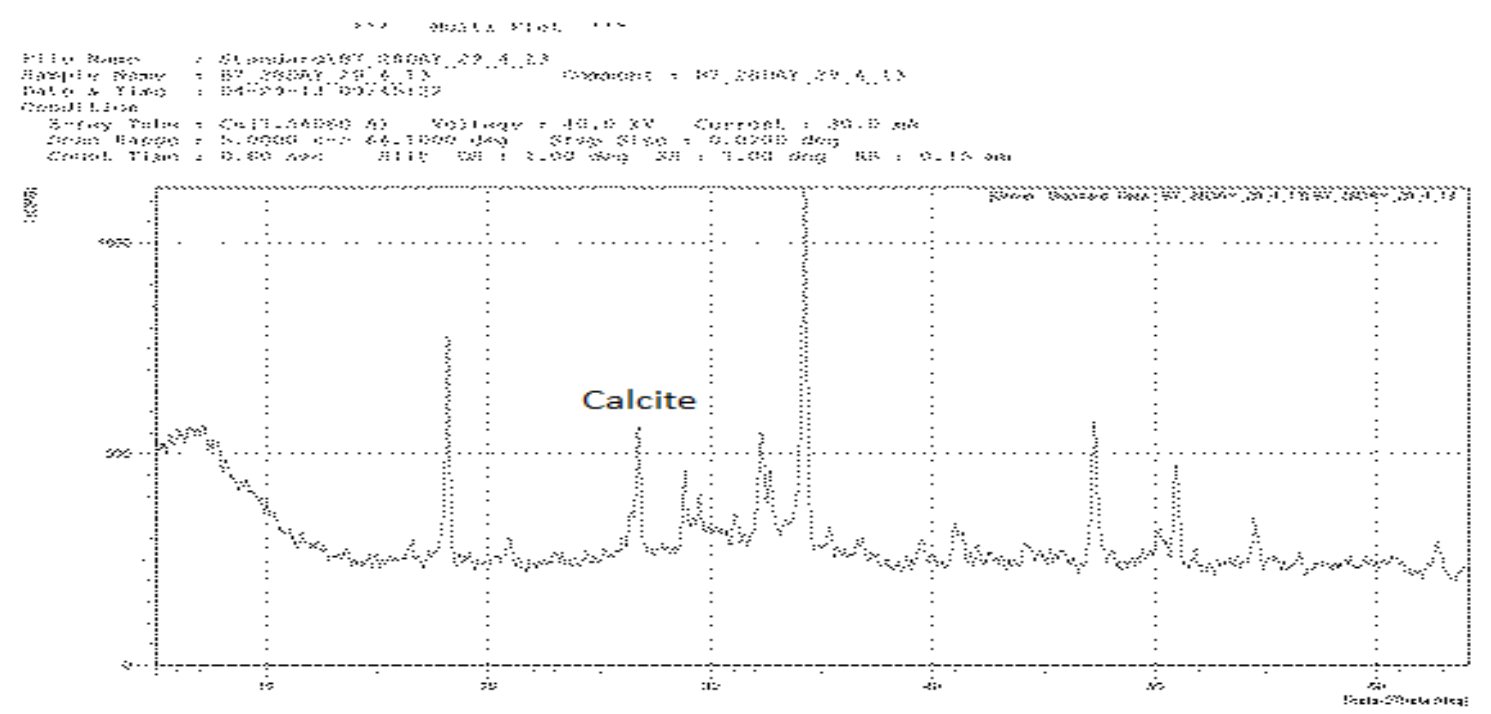

Fig 6 XRD image of cement paste 


\section{CONCLUSIONS}

From the experimental study it can be concluded that the Bacillus Sphaericus and Sporosarcina Pastuerii stains can improve the characteristics of cement composites. The SEM and XRD analysis shows that the presence of calcite inside the cement composite specimens which are produced microbially. These microbes also increase the strength and durability of cement composites.

\section{REFERENCES}

[1]. Kim Van Tittelboom, Nele De Belie, Willem De Muynck and Willy Verstraete, "Use of bacteria to repair cracks in concrete", Cement and Concrete Research 40 (2010) 157-166.

[2]. Jianyun Wang, Kim Van Tittelboom, Nele De Belie, Willy Verstraete," Use of silica gel or polyurethane immobilized bacteria for self-healing concrete", Construction and Building Materials, 26 (2012) 532-540.

[3]. Navneet Chahal, Rafat Siddique, Anita Rajor, "Influence of bacteria on the compressive strength, water absorption and rapid chloride permeability of fly ash concrete", Construction and Building Materials, 28 (2012) $351-356$.

[4]. Navneet Chahal, Rafat Siddique, Anita Rajor, "Influence of bacteria on the compressive strength, water absorption and rapid chloride permeability of concrete incorporating silica fume", Construction and Building Materials, 37 (2012) 645-651.

[5]. Sathesh kumar annamalai, Kantha D. Arunachalam, K.S. Sathyanarayanan, "Production and characterization of bio caulk by bacillus pasteurii and its remediation properties with carbon nano tubes on concrete fractures and fissures", materials research bulletin, volume 47 , issue 11 , november 2012, pages 3362-3368.

[6]. M. Sudhakara Reddy, Varenyam Achal and Abhijit Mukherjee, "Microbial concrete, a wonder metabolic product that remediates the defects in building structures", microorganisms in environmental management 2012, 547-568. [7]. Varenyam Achal, Abhijit Mukherjee, Shweta Goyal, and M Sudhakara reddy, "Corrosion prevention of reinforced concrete with microbial calcite precipitation", materials journal, vol 109, 2012, issue 2, pg 157-164

[8]. J Y Wang, N De Belie, W Verstraete, "Diatomaceous earth as a protective vehicle for bacteria applied for self healing concrete", J ind microbial biotechnol 2012, 39, 567577.

[9]. Varenyam achal and Xianglian pan, "Characterisation of urease and carbonic anhydrase producing bacteria and their role in calcite precipitation", curr microbial, 2011, 62, 894902.

[10]. Afifudin. H, Nadzarah, W, Hamidah M.S and Noor Hana H, "Microbial Participation in the Formation of Calcium Silicate Hydrated (CSH) from Bacillus subtilis", Procedia Engineering 20 (2011) 159 - 165
[11]. Virginie Wiktor, Henk M. Jonkers, "Quantification of crack-healing in novel bacteria-based self-healing concrete", Cement \& Concrete Composites 33 (2011) 763-770.

[12]. Kim Van Tittelboom, Nele De Belie, Denis Van Loo, Patric Jacobs, "Self-healing efficiency of cementitious materials containing tubular capsules filled with healing agent", Cement \& Concrete Composites 33 (2011) 497-505.

[13]. Rafat Siddique, Navneet Kaur Chahal, "Effect of ureolytic bacteria on concrete properties", Construction and Building Materials 25 (2011) 3791-3801.

[14]. Varenyam achal, Abhijit Mukherjee and $M$. Sudhakara reddy, "Effect of calcifying bacteria on permeation properties of concrete structures", J ind microbial biotechnol 2011, 38, 1229-1234.

[15]. Varenyam achal, Abhijit Mukherjee and $M$. Sudhakara reddy, "Microbial Concrete: Way to Enhance the Durability of Building Structures", DOI: 10.1061/(ASCE)MT.1943-5533.0000159. (C) 2011 American Society of Civil Engineers

[16]. V. Ramakrishnan, R. K. Panchalan, and S. S. Bang, "Bacterial Concrete-A Concrete for the Future", vol 225 Pages: 37-54, 2005

[17]. Dr Henk Jonkers, "self healing concrete", INGENIA ISSUE 46 MARCH 2011, pp 39-43.

[18]. Mousumi Bisis, Sudipta Majumdar, Trinath Chowdhury, Brajadulal Chattopadhyay, Saroj Mandal, Umesh Halder and Shinji Yamasaki, "Bioremediase a unique protein from a novel bacterium BKH1, ushering a new hope in concrete technology", Enzyme and Microbial Technology 46 (2010) 581-587.

[19]. Abo-El-Enein, Ali , Fatma Talkhan , Abdel-Gawwad, "Application of microbial biocementation to improve the physico-mechanical properties of cement mortar", Housing and Building National Research Center (2013).

[20]. Henk Jonkers," Self Healing Concrete: A Biological Approach", Springer Series in Materials Science, 2008, Volume 100, 195-204. 